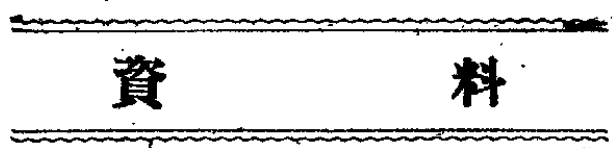

\title{
粘土鑛物の鑑物學的性質 (1)
}

須藤 俊 男

\section{（1）序言}

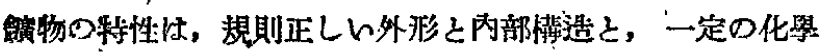
組成であるてとは周知の事算であるが，鋌物の中に江非常て

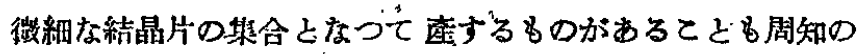

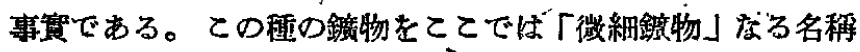

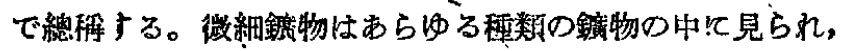

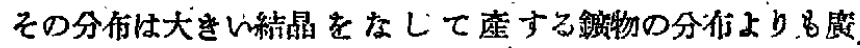

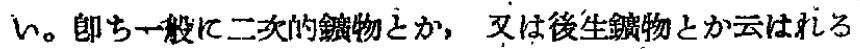

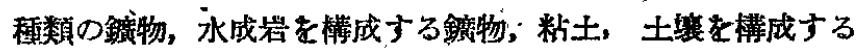

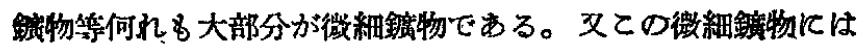

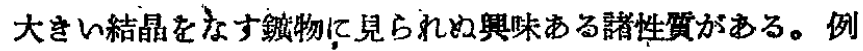

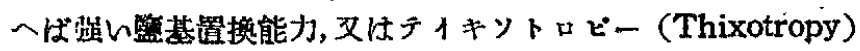

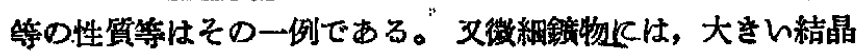

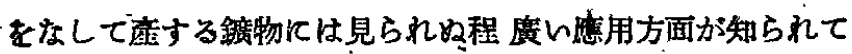

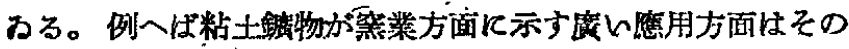
一例であり，酸性白土あ面飞展い利用方面は特飞興味深い所 である。しかるにての微細䤳物の研究は, 從隶著しく掘れて わた。ぞの理由の最も大なるすのは結晶片が微細ですつて,

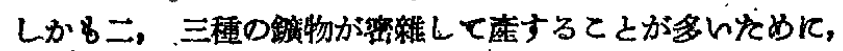

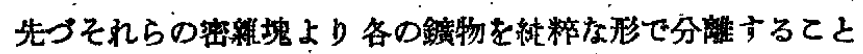
が著しく困奞であり，各の鉝物の結晶㮖造を大きい結晶片を

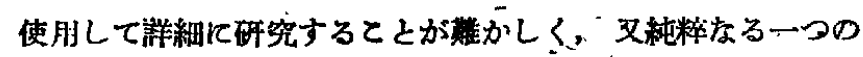

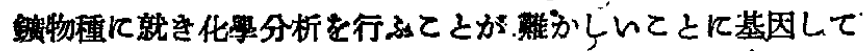
るるのである。かく微細鏡物の研究には国難が件ふが，その

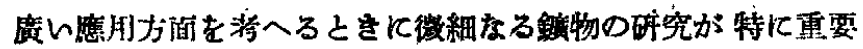

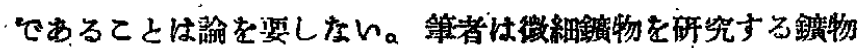
學の一部門を「微細鉞物悬」(Micromineralogy) どして創

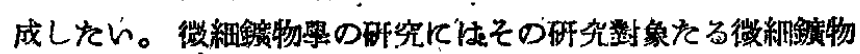

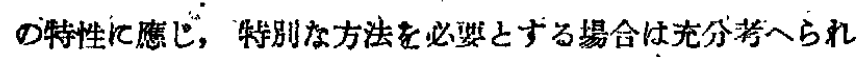

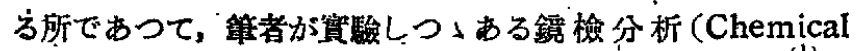

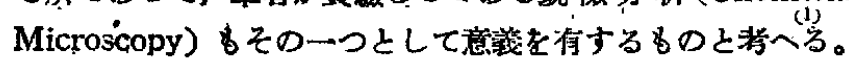

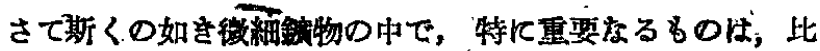

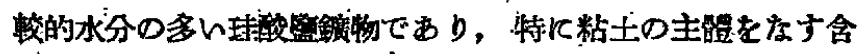

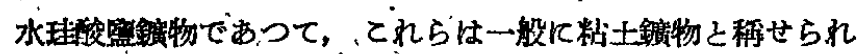
てろるてとは周知の事實である。こてでは篗者がまとめた資

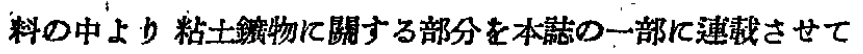
㖪くことにした。

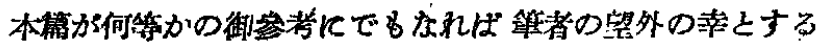

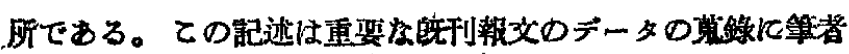

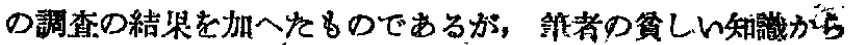

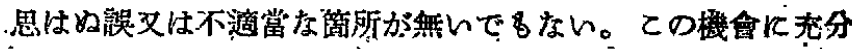
の御批制之御指導を赐はり度んと考入てるる。

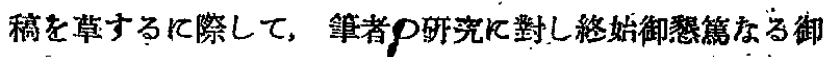

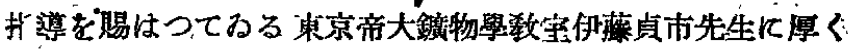

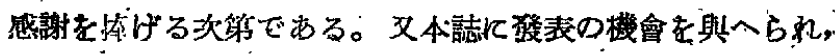

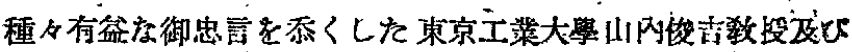

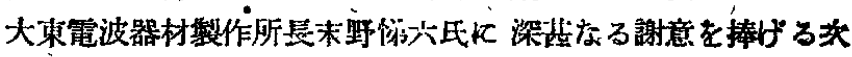

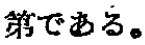

\section{（2）粘士鏣物の分類}

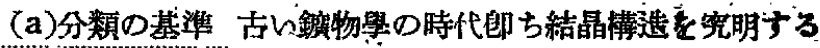

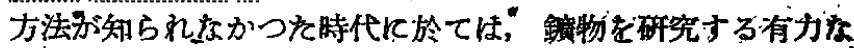
る一つの方法は化學分析であつた。從つてての時代底於ける 銊物の分類は主に化學分析によつたものである。しかし化悬

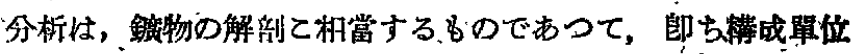

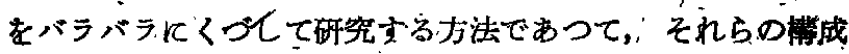
單位が如何に組立てられてらるかて就ては 化學分析の結果の

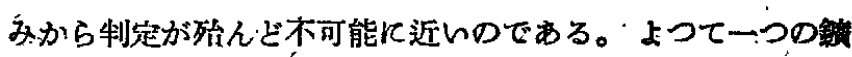

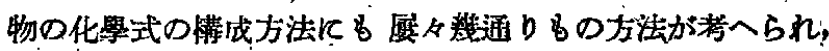

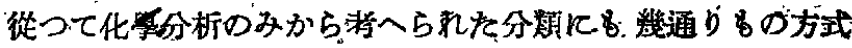

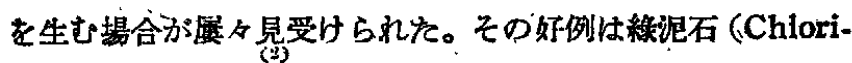
tes)のそれである。

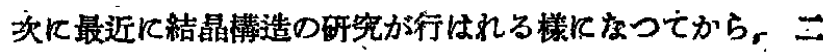
三の重要なる事馆が制明し，一分類の基準が定められたのであ

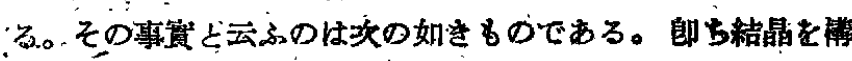

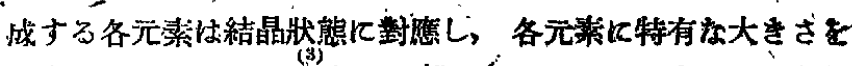

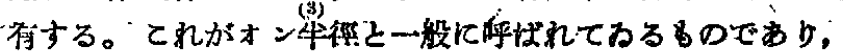

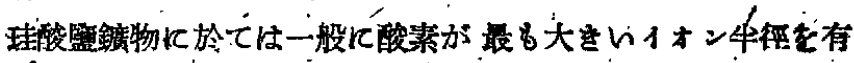

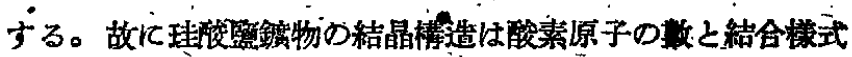

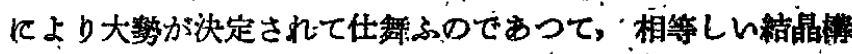

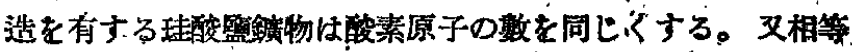

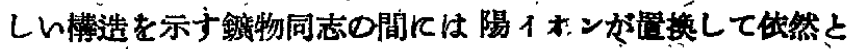

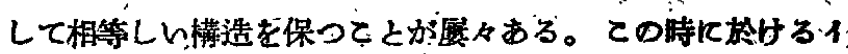

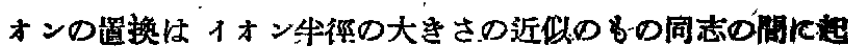

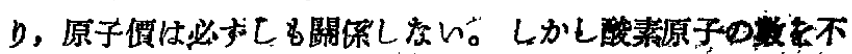

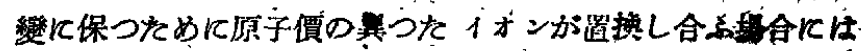

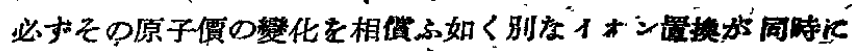

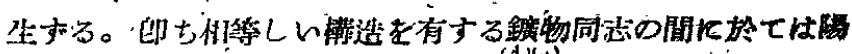

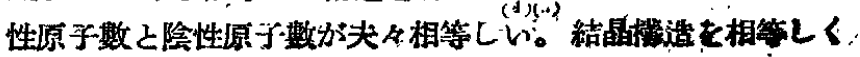




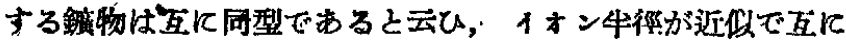
䁂換し合ふイオンを同形イォン列之云ふ。同形イオン列の代 表的な例は, (1) $\mathrm{Mg}^{++}, \mathrm{Fe}^{++}, \mathrm{Ni}^{++}, \mathrm{Mn}^{++}, \mathrm{Co}^{++}$, (2) $\mathrm{Al}^{+++}$ $\mathrm{Fe}^{+++}, \mathrm{Cr}^{+++}$, (3) $\mathrm{Na}^{+}, \mathrm{Ca}_{+}^{++}$, (4) $\mathrm{Si}^{++++}, \mathrm{Al}^{+++}$; 等であ

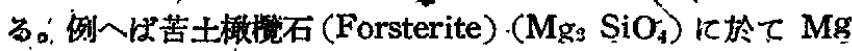

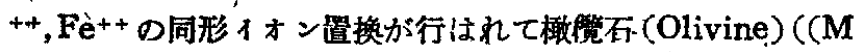
$\left.\mathrm{g}, \mathrm{Fe})_{2} \mathrm{SiO}_{4}\right)$ 生する齐如き例は普通の们であり，曹長不

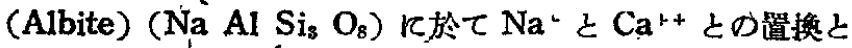

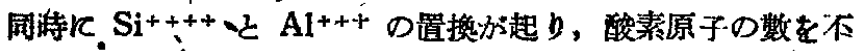
變に保つて灰辰石 (Anorthite) $\left(\mathrm{CaAl}_{2} \mathrm{Si}_{2} \mathrm{O}_{8}\right.$ ) を見出す如きは 他の一例であり，及一般に三價の元素 $\left(\mathrm{Al}^{+++} . \mathrm{Fe}^{+++}\right)$が

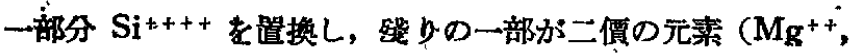

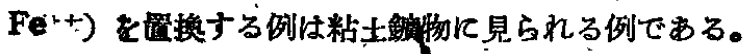

张に二つの化合物があり，その間に同形ィォン置接が見ら れ、，しかをその置換量が連縝して種ななる量に變化してみる 㙏合が見られ，てれら二つの化合物の間に一連の化合物が筫

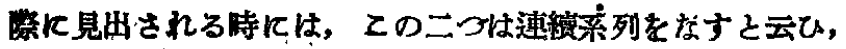

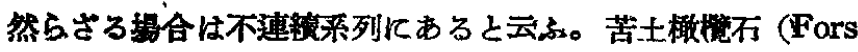
terite) $\left(\mathrm{Mgg}_{3} \mathrm{SiO}_{4}\right)$ と鐵橄筧石 (Fayalite) $\left(\mathrm{Fe}_{2} \mathrm{SiO}_{4}\right)$ は

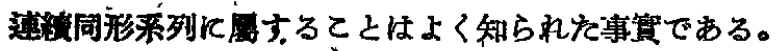

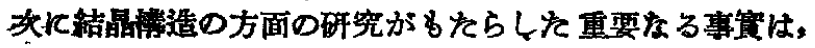

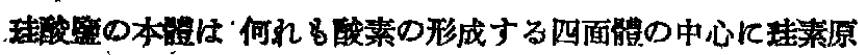

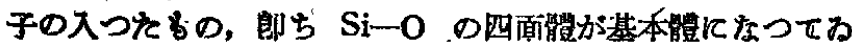

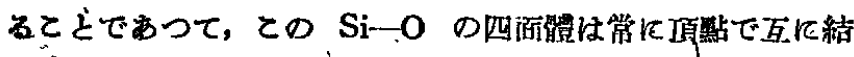

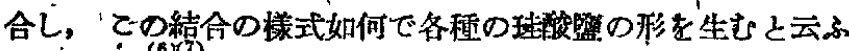

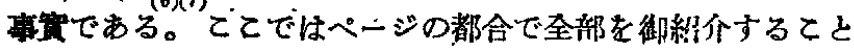

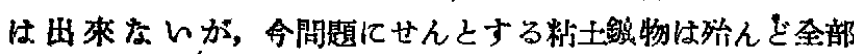
$\mathrm{Si}_{2} \mathrm{O}_{6}$ の型であり一部に $\mathrm{Si}_{4} \mathrm{O}_{11}$ の型がある。 $\mathrm{Si}_{3} \mathrm{O}_{5}$ の刑は

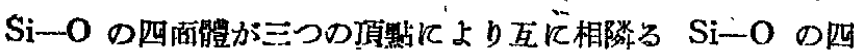

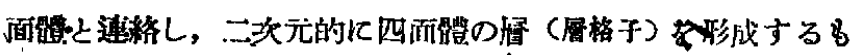

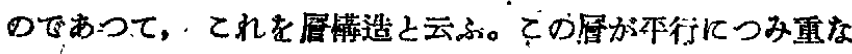

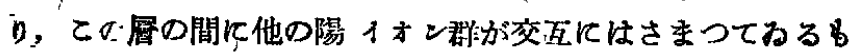

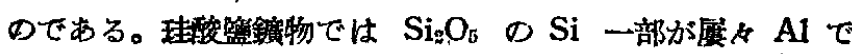
置換さふる。郎ち $\left(\mathrm{Si}_{1} \mathrm{O}_{10}\right)\left(\mathrm{Si}_{3} \mathrm{AlO}_{10}\right)\left(\mathrm{Si}_{2} \mathrm{Al}_{2} \mathrm{D}_{10}\right)$ の如くで ある。一この梅造は外形にあらはれ解狀，镂片狀の外形が示さ

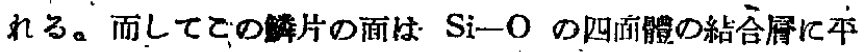

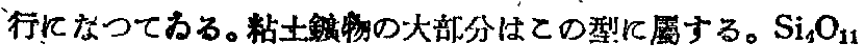
の型ば Si-O の四面體が相瞵る二つ历顶點で鑍狀に蓮結し， この梂な鎮が二本づ小對をなして平行に連結したもので 頪鋇

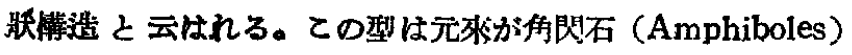

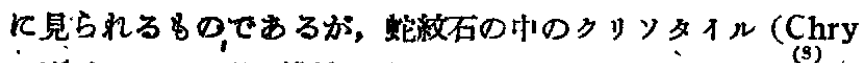

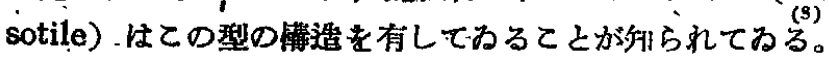

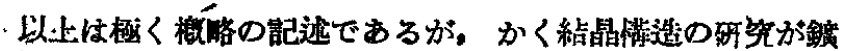

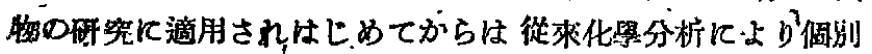

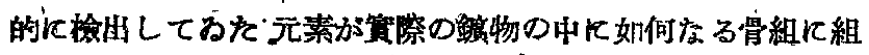
立てられてみるかが明らかとなりっててに鋇物の化學式は棈

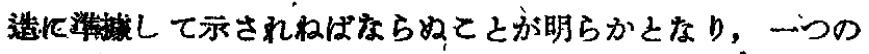

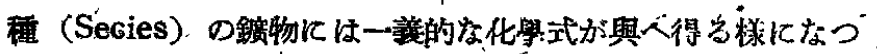

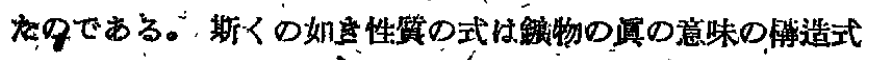

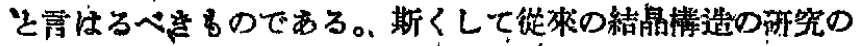

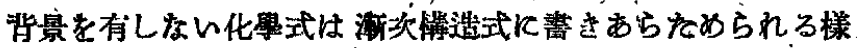
になり，乙の種の仕事が現在の鏔物學の一つの大きな仕事て なづてわる。文斯くの㚼き根本的な意䓺を有する構造圾の決 定は、鍍物の基本的な分類郎ち棈浩の型基售としを分類に

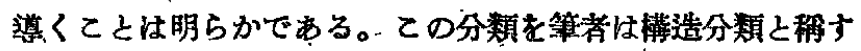

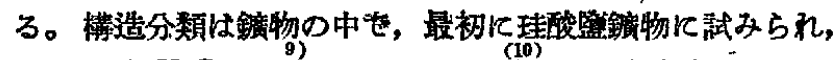
例人ば C.K.Swartz,H. Berman 等により總括報告された， が粘土䌅物の棈造分類は末だ著しく不完全ている。これは既

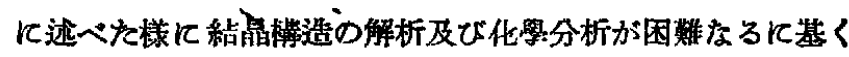
タのである。

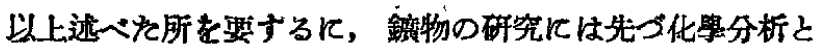
結昆構造の二つの方面の研究の融合が必要であつて，その何 れを缺くる錢物の性質の正しい解明は出來ないてと意味す るタのである。

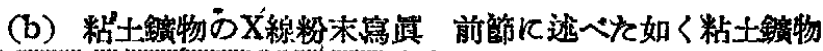

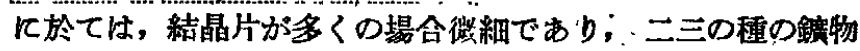

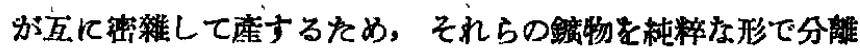
することが難かしく結晶檴造の解析及び純粹なる部料の化

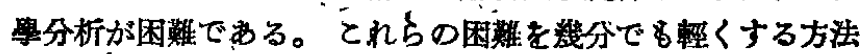

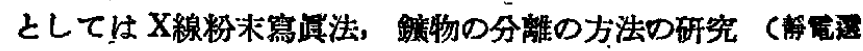
船等) 及び微量分析等の研究が現在の所侾へれらる。こてでは

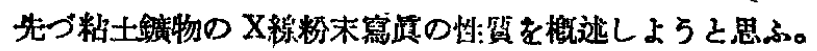

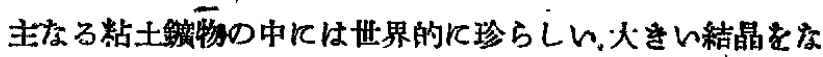
して產する8のもあり，それらにより結品學的の性資は可成

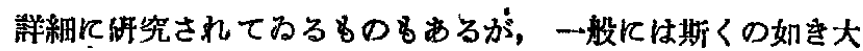

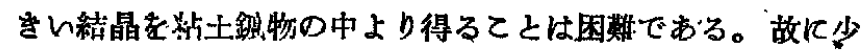

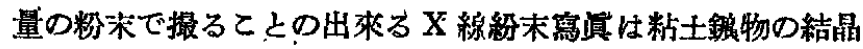
㯕透の方面の性筫の示す唯一のタのである。との意味で粘士

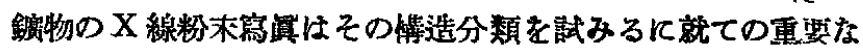
る一方法として探用し得るのである。X楾粉末寫真を特性付

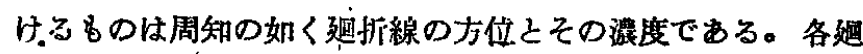
折線の方位には網阙䦌隍が對態するので，普通はての網面閒

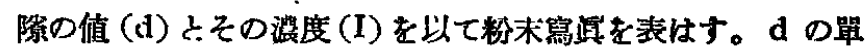
柆はオシグストロームで示す。、个”は簡單のために例へば 「1.5 の線.Jの如く示した淂合は 1.5 オングネトロームの網 面間隙を有する網面より反射せるX楾により生じた粉末線を 意味するものとする。

(吹下の笚位はオングストロームで示すがオングストロームなる 字は咯す!)

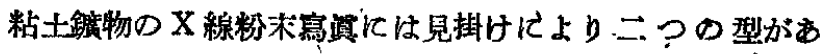

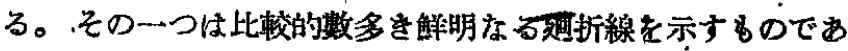

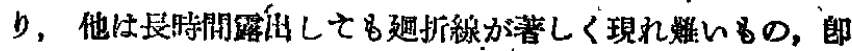
ち数少ない太く不鮮明な迴折總を゙示す型であ゙る。前者を假に A型，後者を假にB犁之名村けると备の例は次の如くである。 A型，パイロフィラィト (Fyrophyllite), 滑石 (Talc) 維泥 石 (Chlorite), カオリン (Kaolin). 等

B型, そンモ! ロナイト (Montmòrillonite), デュウェラォ i (Deweylite), ハャイサオト (Halloysite) 
るとよりでの二つの型は確然と分け得られる性䨘のるのてな

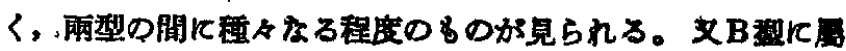

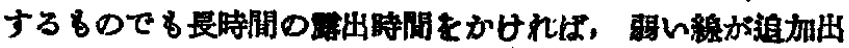

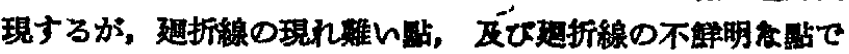

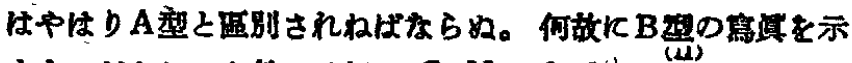
ナものがあるかと就ては既に G. Nagelschtidt が冒及した

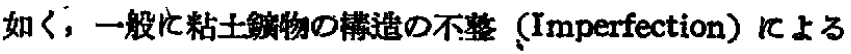

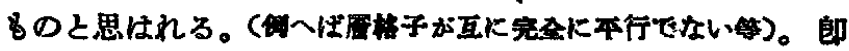
ちB型の寫而をナるのでは A型を示するの上 b不整の程度

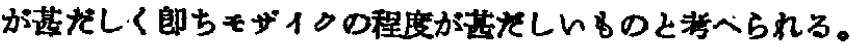

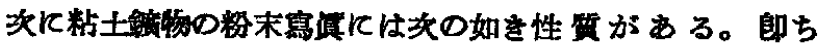

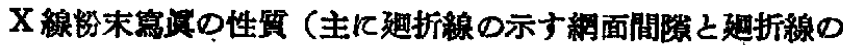
源度に示される）には特有性之偶然性とがある。而して二つ

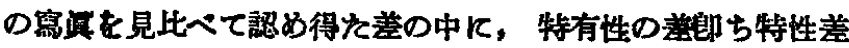
と㑭然性の差即ち偶然羔とがある。るよりての中で特有性 之特性善を間題とせねばならない。例へば站生鏡物の中では

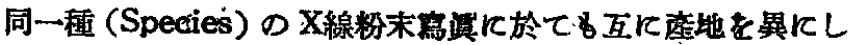

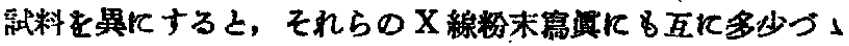
異なる所があると云ふ事赛がある。ての㩆を明らが示摘さ れた例は A. F. Hallimond に上り研究された鐵杽泥石の一 㮔のシャそサイト(Chamosite) の桝である。斯くの如き場 合に見られる差住假然差と一態考へてよんるのと思はれるが， A.F. Hallimond は斯くの如き差の認められる原因として,

（1）粉末詰料をつくる時の結晶片の方位度の签化，粉末の粒

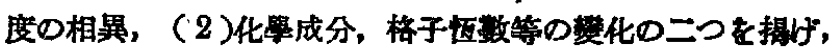
（1の原因に就ては教的いきととを述一，（2）の原因に就て

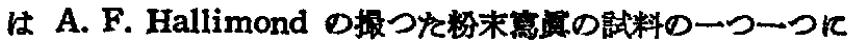

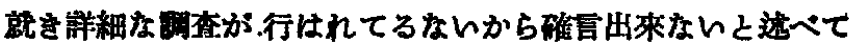

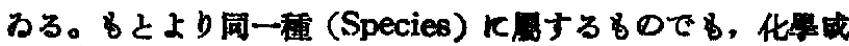

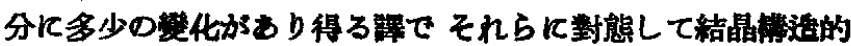

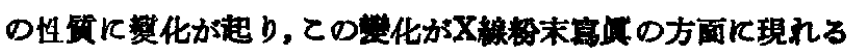

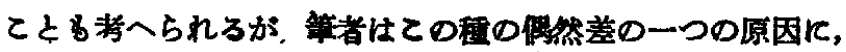

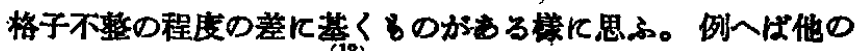
一例としてJ.W.Gruner の示したノントロナイト (Nontro nite) の.X 線粉末寫政には可成舆特間の露出時間をかけて得

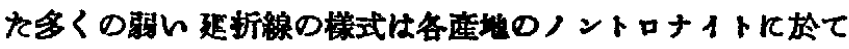

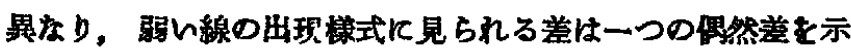

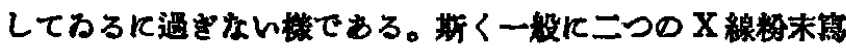

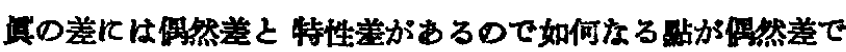
あり，如何后る呫か特性差であるかと判定ナる必要がある。

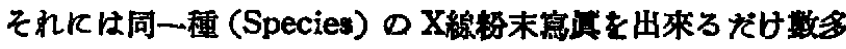

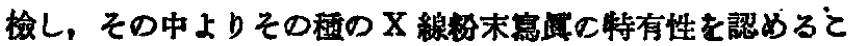
とが必要である。外國報文に於ては樶近飞粘土物の矿究の

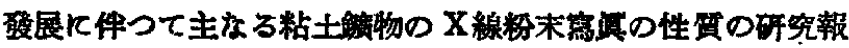
文が見られはしめめて來た。篗者は內地で手に入れるてとの出

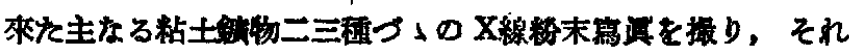

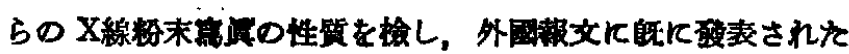

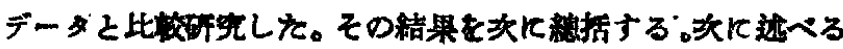

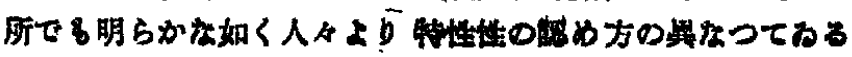

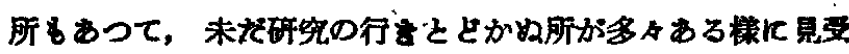
けられる。

一般に云つて（1）特性性は强口通折線の样式に見られ偶然

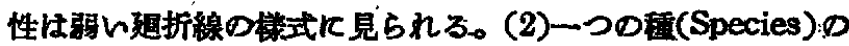

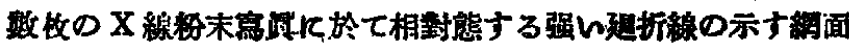

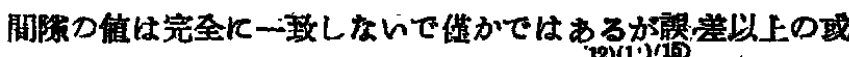

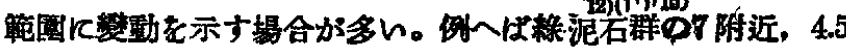
附近，3.5附近の線の如くである。これは僻然性と見られるか 後は一Dの線を指示する場合に「何々オンク゚ストローム附

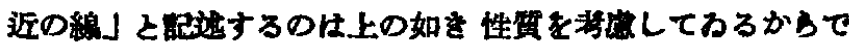

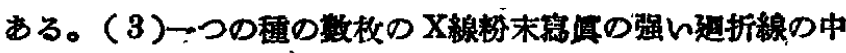

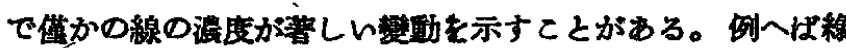
泥石の 4.5附近の線の如くである。てれる佩然性として取扱 はれる。(4)一本の線归明らか飞複線に分れる場合 又はをの

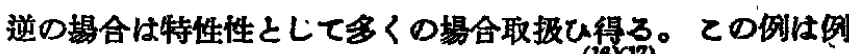

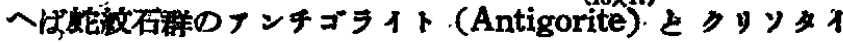

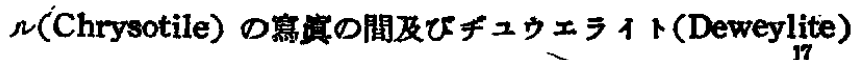

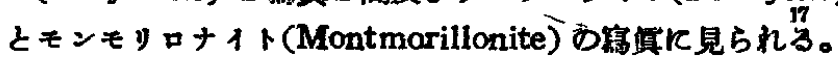

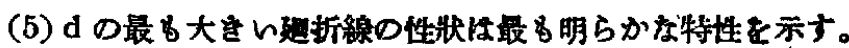

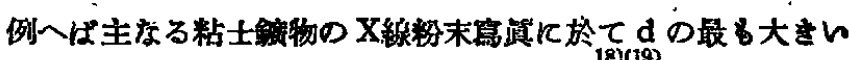
奋折線を一括表示ナれは第 1 表の如くである。

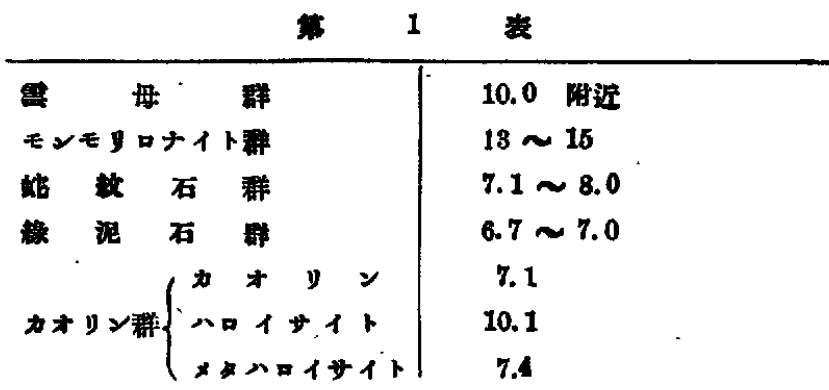

即ちモンモりロナイト群が最る大きり値を示す。ねか斯の

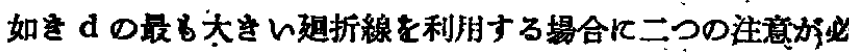
要である。即ちその一つはての種の線は歷ネカメラの穴にさ へ它られて、フィルム上て卵せられないてとが多いてとです

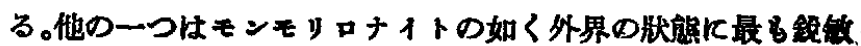

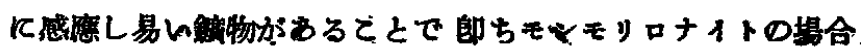

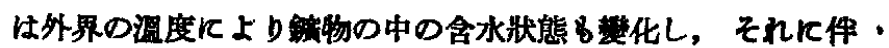

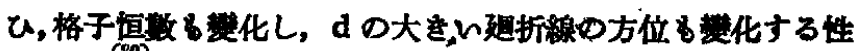

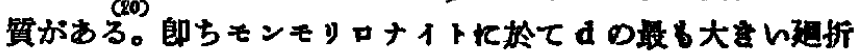

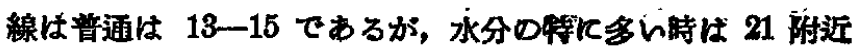
まで连し， $200^{\circ} \sim 500^{\circ} \mathrm{C}$ 几乾かすと 9.6 附近の值をホし, 雲母群のそれに近づんて來る。

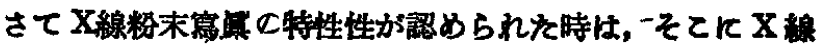

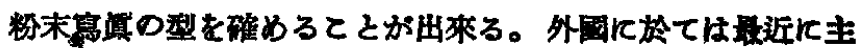

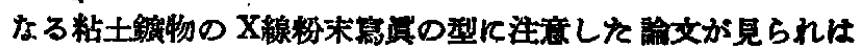

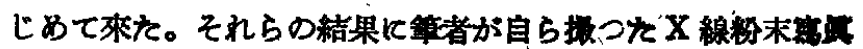

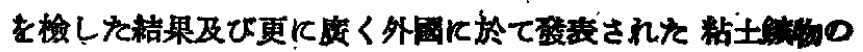

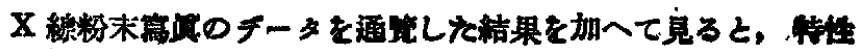

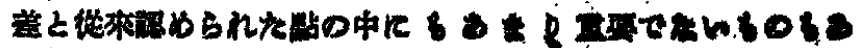




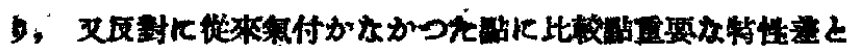

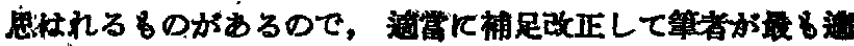

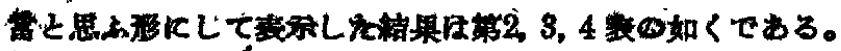

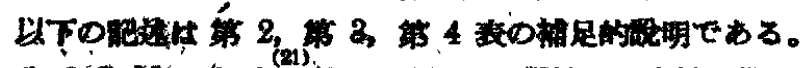

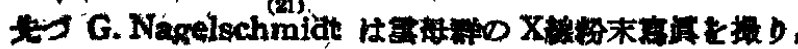

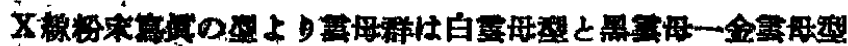

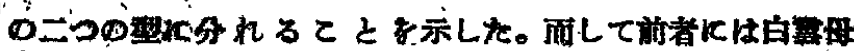

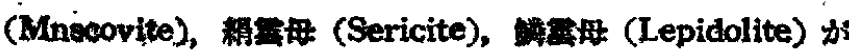

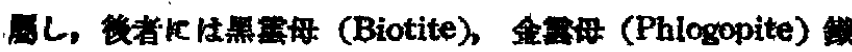

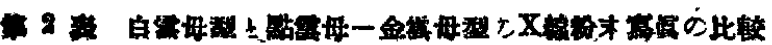

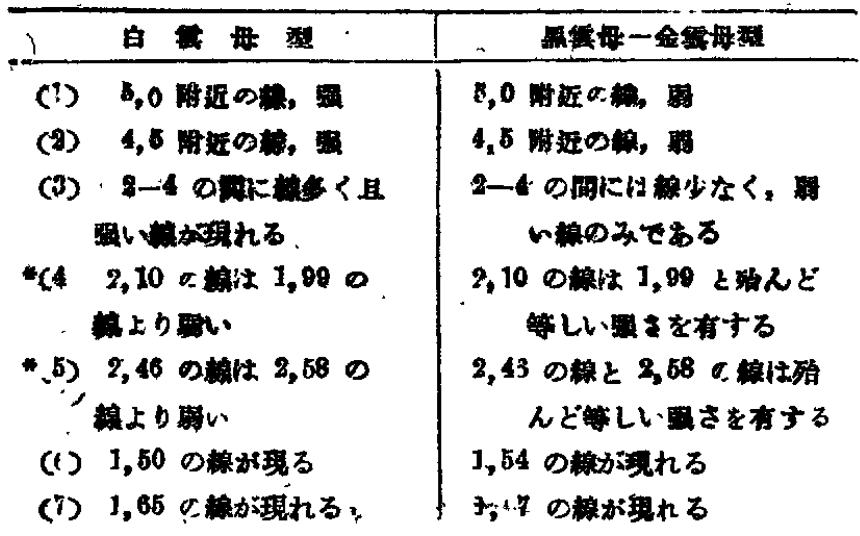

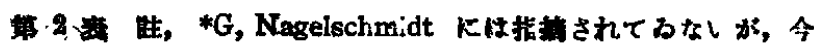

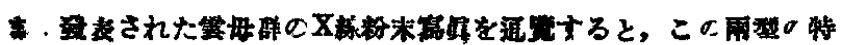
性差になり得る。

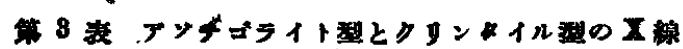

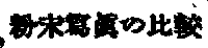

\begin{tabular}{|c|c|}
\hline アンチニ゙ライト犁 & 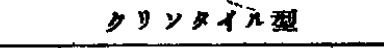 \\
\hline 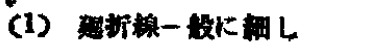 & 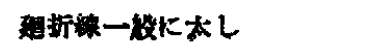 \\
\hline (2) 4,6 咐新。楾（例へば & 4,6 倠近の楾(例人ば 4,58) \\
\hline $4,70 \mathrm{~m}$ & 蜋 \\
\hline 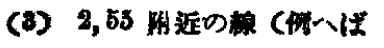 & 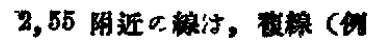 \\
\hline 2,55$)( \pm .196$ & 人は: 2,61, 247) \\
\hline 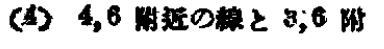 & 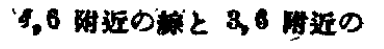 \\
\hline 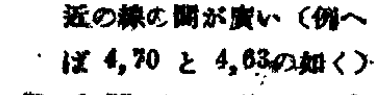 & 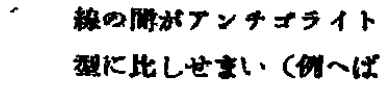 \\
\hline 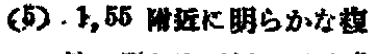 & 4,18 \& 3,60 の如( ) \\
\hline 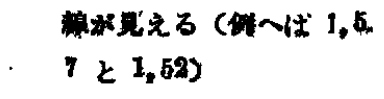 & 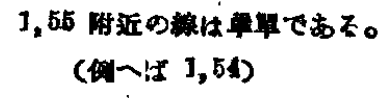 \\
\hline
\end{tabular}

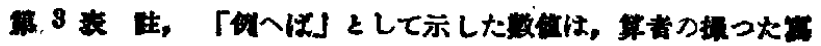

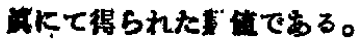

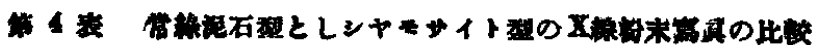

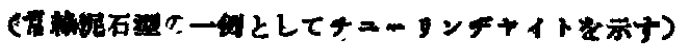

\begin{tabular}{|c|c|}
\hline メニーリンデヤイト & シヤモサイト \\
\hline 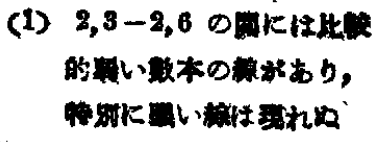 & 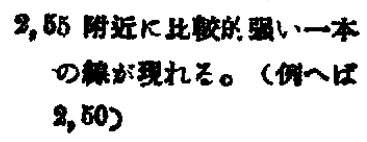 \\
\hline 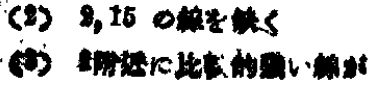 & 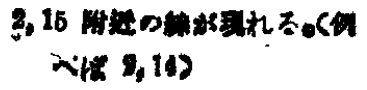 \\
\hline
\end{tabular}

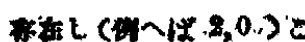
the per 1,8-2 Datio Di. zo

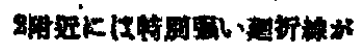
明瑟しないことがく、

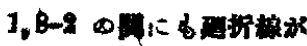
少ない。

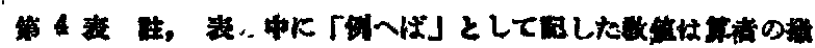

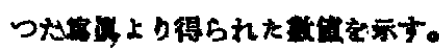

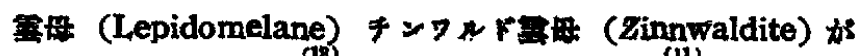

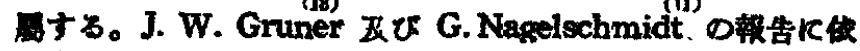

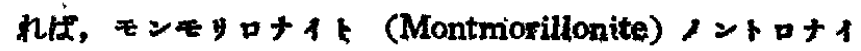

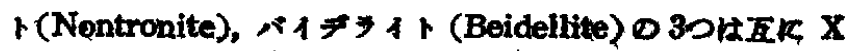

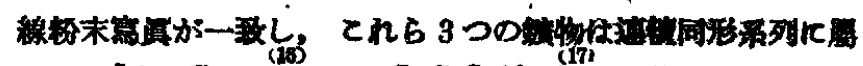

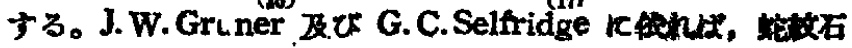

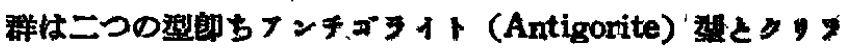

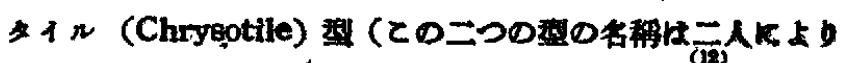

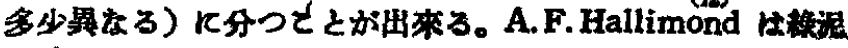

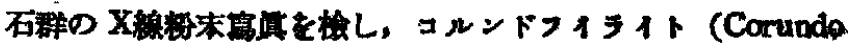

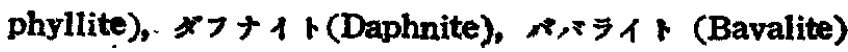
チニーリンヂイト (Thuringite), フフロシテライト (A) hrosiderite) は一サイト(Chamosite), アメサ1ト (Amesite), クロンス

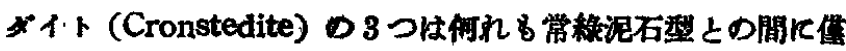

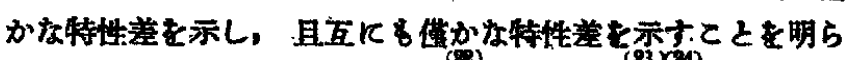
がした。 及, G. Nagelschmidt, M. Mehmel 及び C.W. Correns はハロイサイト (Halloysite) の稀末言期論し，

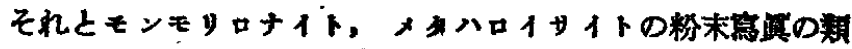

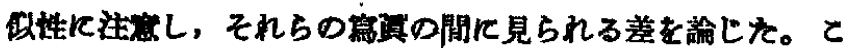

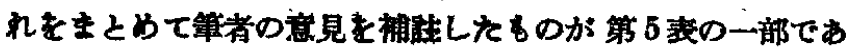

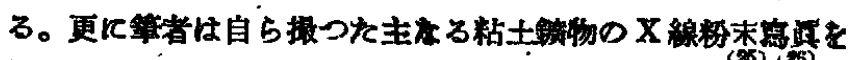

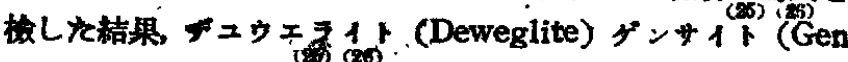

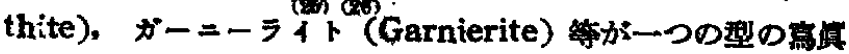
を示すとをを㒛め，てれをチュウエライト型とした。而して とのヂユゥェライト型はモとモタロナイト㤠, ハロイサイト

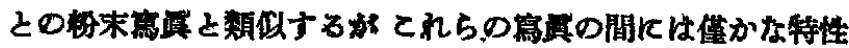

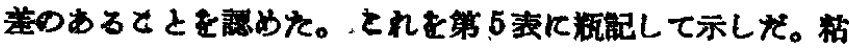

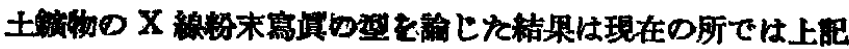

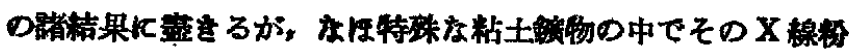

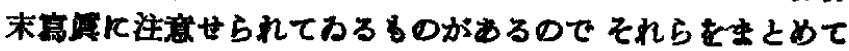
以下K記する。(未完)

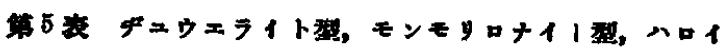

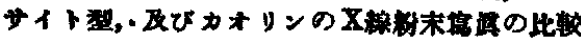

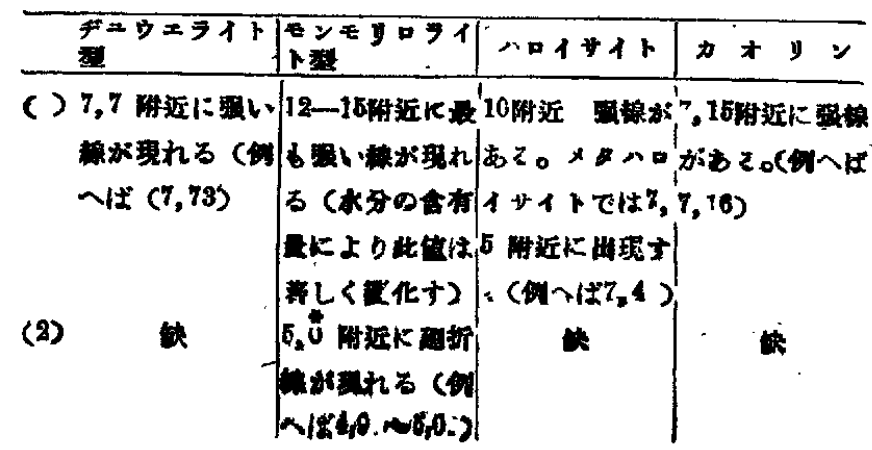




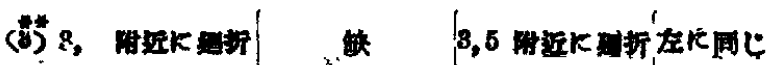

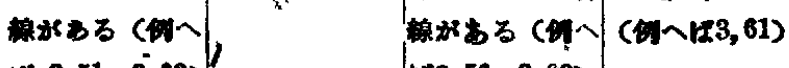
स* $8,51-3,63)$

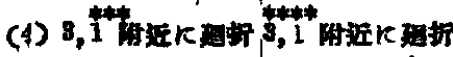

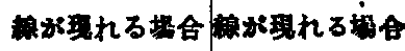

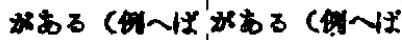
$8,15-8,26) \quad 8,10-3,15)$

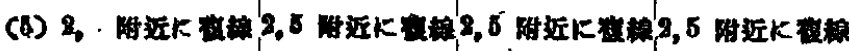

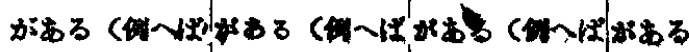

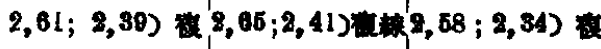

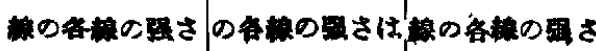

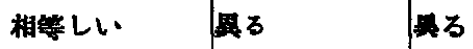

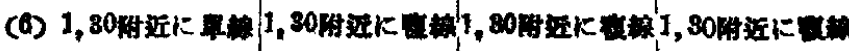

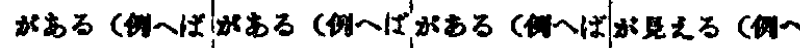

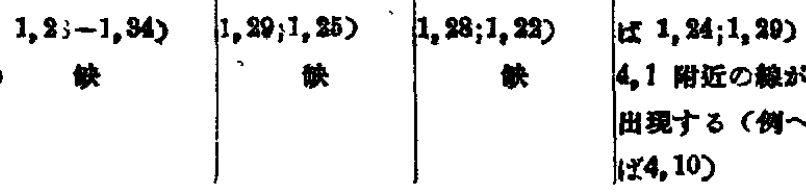

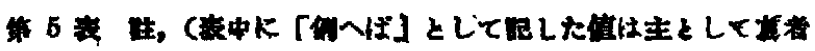

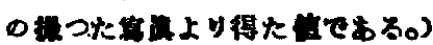

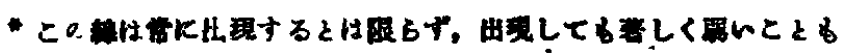

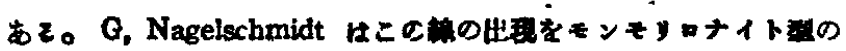

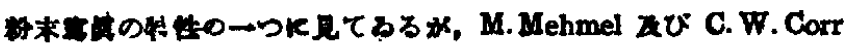

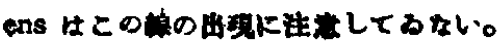

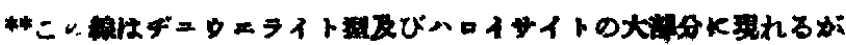

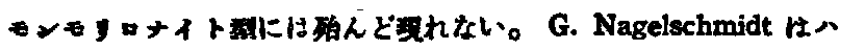

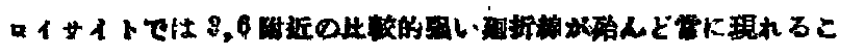

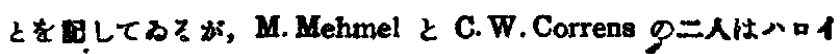

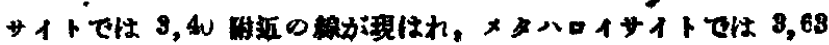

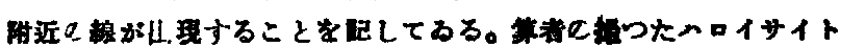

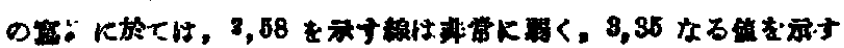

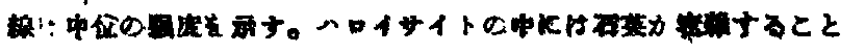

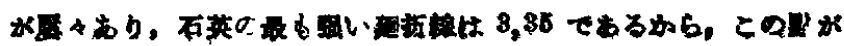

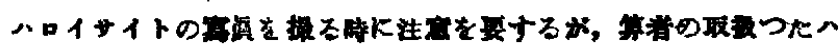

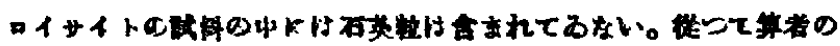

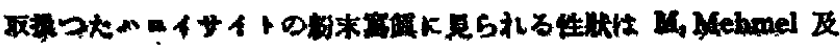
U C. W, Correns $\sigma$ 枯果以近l 。

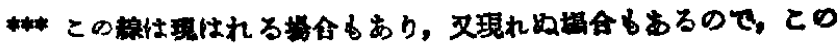

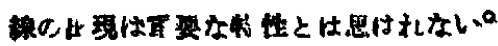

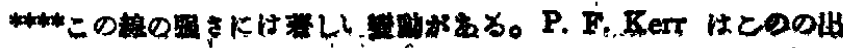
現はサホンイ

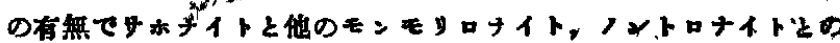

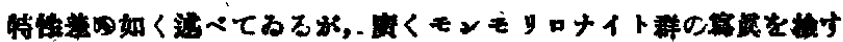

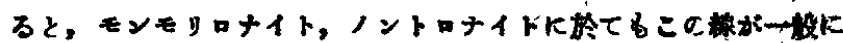

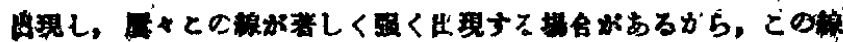

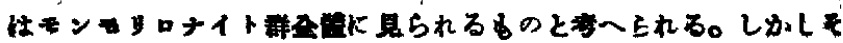

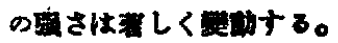

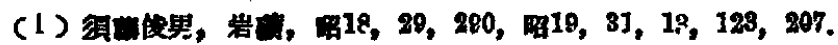
274, 暗 18, 32, 111

(2) J. Orcel, Bull soc. franc, miner., 1627, 50, 75

(8) L. Laves, Natwrwiss, 1687, 25,722

(4) E. Eitel, Plyzikalische Chemie der Silikate, 1941, 45

(5) W.L. Bragg, Atomte Strweture of Ifinerals. 1987, 37

(日) E Eitel, op, cit., 1941, $\theta$

(7) W. L. Bragg, op. cit., 1987, 1so

(8) R. E. Warren and W. L. Bragg Z. Krist, 1980, 76, 201

(9) C. K. Swartz, Am. Miner, 1637, 22, 1.61

(10) H. Berman, Am. Miner., 1937, 22, 342

(11) G. Nagelschmldt, Miner. Mag., 1898, 25, 140

(12) A' F. Hallimand, Miner. Mag. 196, 25, 441 .

(19) J. W. Gruner, Am. Miner., 1985, "47, 475

(H) R. C. McMurcky Z.Krist, 1034, 88, 420

(16) A. N. Winchell, Am. Naner., 192", 19, 161

(16) J. W. Gruner, Am. Mimer., 1 97, 2 " 87

(17) G.C. Selfrldge, Am. Miner, 1936, ฮูป, 463

(16) G. L. Clark, F-F. Rieken, and D.H. Reyitold, Z. Krist, 1037, $P, 237$

(18) G. L.C ask, R. E. Grim. and W.F. Bradley, Z. Krist., Ifa? 20, 322

(8) U. Hormand, E. Endell und D. Wim, Z. Krikh, 1989, 86 340

(21) G. Nagelcetmidt, Z Kriet, 1087, 07, 64

(28) G. Nagelschmidt, Z. Krist., 1834, 87, 120

(23) M. Mehmel, Z. Krist, 1935, 90, 35

(24) C. W. Correns and M. Mehmel, ZnKrist., 19:6, 84, 337

(25) T. Sudo and T. Anzai, thec. Imp. Acod. Soi, Tokyc, 1042, 18,400

(20) T. Sudo, Bull. Chem. Soc. Japan, 1949, 18, :81 